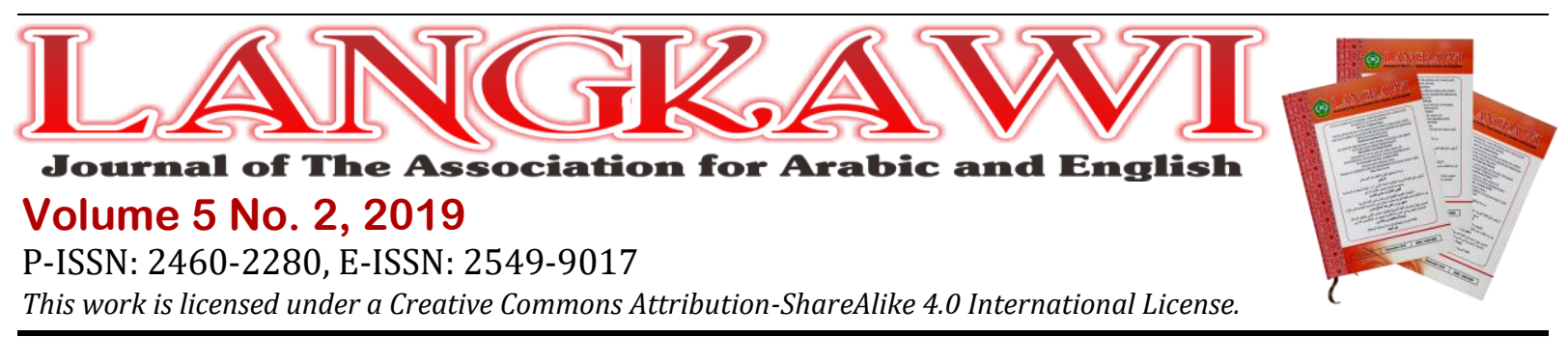

\title{
Developing IELTS Material through Schoology to EFL Learners' Listening Comprehension
}

\author{
Hesti Rokhaniyah', Shoffin Nahwa Utama² \\ 1 University of Darussalam Gontor, Indonesia.E-mail: hesti.r@unida.gontor.ac.id \\ 2University of Darussalam Gontor, Indonesia. E-mail: shoffin@unida.gontor.ac.id
}

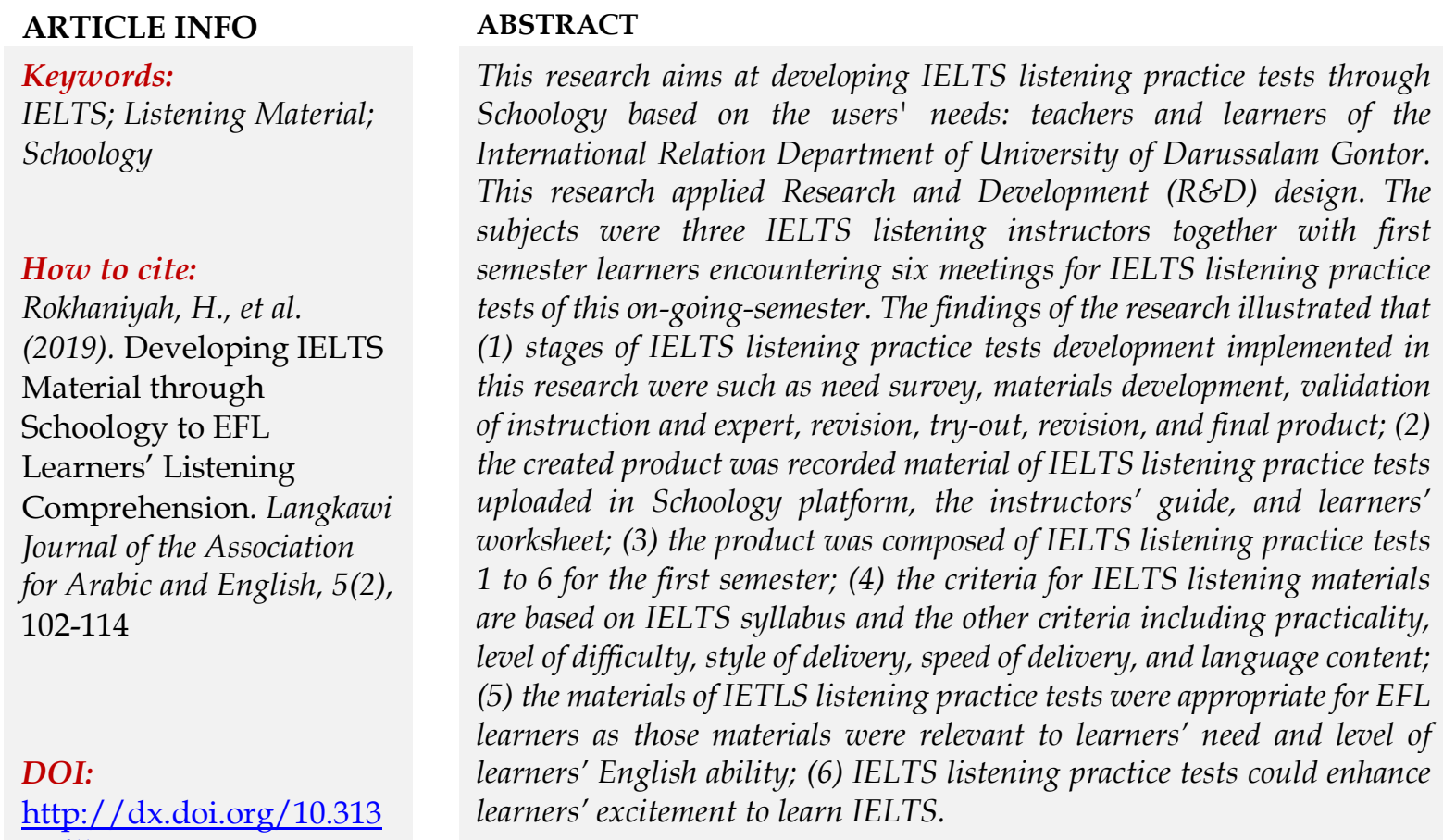

\section{Introduction}

Listening is a language skill, and it can be improved through rehearsal. In Content and Language Integrated Learning (CLIL), learners should obtain the proper materials to listen to (Yeldham, 2018). The materials provide a variety of forms: lecturers' input, peer interaction, and information source (film, recorded lectures, as well as tutorials). In EFL class, an audio-lingual method is regarded as essential for learners to enhance their pronunciation and comprehension. Celce (2001) revealed that the audio-lingual method had some characteristics such as new material was presented in dialogue form, great significance was attached to pronunciation, and there was a tendency to understand the context. Liubiniene (2019) defined that the role of listening comprehension was as a tool to understand the process of teaching and learning language. Gilakjani \& Ahmadi (2011) argued that listening was a complex process in interpretation, and listeners had to match what they had heard with what they had already known.

Listening comprehension was categorized into two distinct processes (Ahmadi, 2016). When learners implemented prior knowledge to comprehend the meaning of conveyed messages, they used the top-down process prior knowledge involved the 
knowledge of the topic, listening context awareness, the type of the text, and the culture which was held in long-term memory. The process of top-down meant how learners use their knowledge for attributing meaning to the input of language; how the social convention knowledge assisted them in understanding the meaning. It included the information for bearing the task of heard language comprehension (Batova, 2013). However, bottom-up processes happened when learners understood language sound by sound or word by word; they used linguistic knowledge to understand messages. They listened to a sequence of sentence patterns with rising or falling intonation, discriminated among phonemes, differed final consonant, or selected listening for morphological endings (Ahmadi, 2016).

According to Liubiniene (2019), listening comprehension was an interpretative and interactive process in which the listeners implemented either prior or linguistics knowledge to derive the messages. The interpretative process belonged to the process of interpretation in which the listeners matched what they had heard with what they had already known. The interactive process, on the other hand, asked listeners to work at constructing the meaning from the sounds listened by their ears, which they used as necessary (Batova, 2013). The process of top-down and bottom down was at work in the listening. It was continuum the learners learned toward one process as it depended on learners' language knowledge, topic, and listening goal (Yeldham, 2018). If the aim of listening established before the listening task, learners have purposes. Therefore, they will decide which to activate one of the processes

International English Language Test System (IELTS) is an English proficiency test measuring the ability of listening comprehension, reading comprehension, writing, and speaking (Tabrizi, 2017). IELTS has two versions: the academic training system and a comprehensive training system (Chalmers \& Walkinshaw, 2012). The academic system is intended for those who want to study in an English-speaking country. However, the overall training system is for those who want to gain experience or to immigrate to the English-Speaking-Country. IELTS has a band score ranging from 1 to 9, which is from non-user to the expert user

Schoology was a web-based social network used to facilitate users to create, manage, and interact with each other and share academic content (Atmoko, 2018). Schoology was an innovative platform built on inspiration from Facebook (interface and model, fundamental aspects of the presence of posts, status updates, instant sharing, and updating) and with the right goals to become a learning tool. Schoology had several advantages including (1) providing more choice of resources; (2) accommodating the type of question (question bank) that would be used during the quiz; (3) facilitating learners' attendance used to check their attendance; and 4) providing analytical facilities to see all student activities on each course, assignment, discussion and other activities prepared for learners (Tigowati1 \& Efendi, 2017)

EFL textbook applied in the IELTS Listening class has been using the top-down listening process. Based on the lecturers' teaching experience in listening class, learners are asked to listening skill, for example, listening for map labeling, listening for numbers and letters, form completion, and multiple choice. Learners need to listen effectively, although they have unfamiliar lexical resources. If learners get the point of a few words from an incoming signal, sometimes the context is insufficient for them to comprehend the conveyed message. Learners have quickly got blank in the 
meaning. This condition somehow leads learners to frustration; it affects their motivation to enhance their listening skill

To assist learners in comprehending the either emotional or mental process in listening, lecturers with proper teaching materials can let them discover the essential aspect of listening. Recent literature illustrated that designing material based on Contextual Teaching and Learning Approach was only crucial because the approach helped learners connect the materials' content, which they were learning to the prior skill and context of life (Zulyadaini, 2017). Designing material for listening is so challenging: it rewards as designing material based on the Contextual Teaching, and Learning Approach provides what learners require and helps them understand the materials as well.

Since its establishment, the University of Darussalam Gontor has paid more attention to English as the primary language in the learning process. It proves that the University of Darussalam Gontor is likely to become a world-class university. However, the use of methods in language learning needs to be improved in order to create more effective learning. This research was conducted due to students' low activity and learning outcomes in IELTS listening courses. Likewise, those lecturers did not vary their learning media, and there was no structured instrument to know and evaluate students' ability levels. In the process of learning English as a foreign language, tests are one of the evaluation forms of the teaching and learning process. Therefore, the need for an ideal test is quite needed to evaluate listening skills to EFL learners. Based on the background of the study above, the problem of the research could be stated as follows: What IELTS listening practice test was appropriate for EFL learners' listening comprehension.

Meanwhile, the developed product specification was suitability, syllabus, and curriculum-based and usability in the classroom or language laboratory. The products were composed of recorded materials that were provided through the Schoology platform and instructors' manual. The instructors' manual consisted of the tape scripts along with the answer keys.

\section{Literature Review}

Related to the recent study on developing listening material for English foreign language (EFL) learners, some researches had been conducted. First, Syafi'i (2016) researched English development as a foreign language listening material for learners in Islamic high school. The observation showed that the English listening skill of learners in the tenth graders was not well developed. As a result, the listening instruction materials needed to be advanced. The researcher's product was materials for teaching listening for tenth grades consisting of teacher's guidebook, and the compact disk. During the try-out of the product, the participants were enthusiastically doing the exercise. They joined the listening class with a fun atmosphere as it helped them increase their listening comprehension.

Second, Syafi'i \& Gestanti (2017) developed listening material for the eighth graders. The final product of the research was listening to the material for eighthgraders, including learners' worksheets, a guide book for teachers, and the compact disc containing material for listening. Also, the research developed a form of a lesson designed in a systematic format such as learning objectives, pre-listening, whilst- 
listening, and post-listening, as well as expansion activities. The products could enhance learners' motivation to learn English. It was because the content of the materials was considered novel for them, and the product involved a religious aspect.

Similarly, Yaniafari carried out the research focusing on developing multimedia-based listening materials for $1^{\text {st }}$ grade students of SMK. The aim of the study was providing a package of interactive $\mathrm{CD}$ for learners in self-learning activities together with teaching-learning activities in the classroom. The media was designed to resemble the game simulation. It contained audiovisual material, exercise, and follow up activities to let learners feel enjoyable and fun. Having got the try-out, learners could fully utilize the media for self-study since it had been designed for that purpose. Moreover, a teacher could use it as new media in the teaching-learning process as exercise and more follow up activities.

The previous researches can establish the theoretical framework for this study. There is a similarity between the researches mentioned above and this research. It is undeniable that the previous researches deal with the developing material for listening comprehension. In this research, the developing material is also for learners' listening skills. Instead of similarity, it is found out that the previous studies focus on the material for listening subject; however, this research is carried out to evaluate learners' listening ability in IELTS.

The developed material for IELTS listening skills was for the first-semester of International Relations. Learners in the first semester were beginner level listeners. Thus, the technique implemented in listening comprehension had to match the beginner-level listeners. Following this, Brown (2001) recommended eleven techniques as well as the goal. The first five techniques referred to bottom-up: (1) discriminate the intonations in the sentence. This activity aimed at listening to sentences pattern with both rising and falling intonation. (2) Discriminate between phonemes. The activity was addressed to the purpose that was listening to word pairs. (3) Listen to selection for morphological endings. (4) Select details from word recognition. (5) Listen to regular sentence word order. The activity referred to listening to a short dialogue and filling in the blank in the provided questions.

The second of three techniques belonged to top-down rehearsal: (1) discriminate emotional reactions. The activity had the purpose of listening to utterances describing the emotional reaction that learners hear. (2) Get the sentence gist. The activity included listening to sentences that describe a picture; learners select the proper picture. (3) Recognize the topic. This activity could be done through listening to dialogue and learners decided where the dialogue happened, listening to the conversation, and seeking the greeting card picture to decide which of the greeting card was sent, and listening to a conversation to determine what the speakers were talking about.

The last three techniques were an interactive exercise. (1) Build a semantic network. This activity aimed at listening to a word and associating the words that came to mind. (2) Recognize familiar words and relate them to the category. The activity was listening to the words form a list required in the worksheet and matching each word based on the speakers said. (3) Follow the direction could be done through listening to a description of a route on a map. 
In developing instructional materials, the first step done is need analysis. According to Hyland (2003), needs analysis required many aspects including learners' goal, proficiency, and teaching preferred. Similarly, needs analysis gave the contribution to determine what appropriate material should be taught. It became a good idea to decide the criteria before instructors applied recorded material for IELTS listening practice tests. The curriculum would be the basis for developing materials. The materials applied to catch up instructional objectives should be based on the curriculum along with the syllabus. The materials also covered consistency and relevance. Consistence included the consistent relation to the competence while relevance meant the materials' level of difficulty should be appropriate with the level of learners' intellectual development

Hyland (2003: 99) assumed that the developing materials steps had to undergo five ways: (1) adding which was composed of book supplement offering reading, task, and exercise; (2) deleting which focused on omitting irrelevant along with unhelpful items; (3) modifying which dealt with reconstructing the rubrics, activities, example, or explanation for improving the clarity; (4) simplifying which concerned reducing the difficulty of task or the instruction; (5) reordering which related to changing the activities in order to fit coherence with the goal of the course.

Furthermore, Underwood (1993) argued that the prototype of listening materials had to develop based on the need survey data, which included the aspects of language, content, length, delivery style, speed, recording clarity, difficulty level, practicality, suitability with the syllabus, and effectiveness. The third phase was the expert's validation in order to obtain the requirements' criteria of useful material, including the language, style, and content. (1) The language should be the right level; (2) the style should have a minimum variety of speech; (3) the content should lessen learning difficulty.

Also, using understandable content was recommended to lessen the learners' burden. The burden could lead to the learner's problem, and they needed to cope with during listening comprehension. Learners did not identify what sounds occurred, how fast the dialogue is spoken, what intonation's significance was, or whether the speaker got furious or patient. To produce straightforward text, abstract contents, as well as jargon words, had to be evaded. Materials had to engage learners' awareness and let them want to listen. In order to provide significant effects on foreign language teaching, amusing picture or engaging stories could be exploited. Besides, the instructors' role had to be so creative; learners would enjoy the teaching-learning process. The outcome of this research facilitated the IELTS listening class with available materials that were compatible with listening for IELTS and also provided Schoology to access IELTS listening practice tests.

\section{Method}

Preliminary research on IELTS competence of International Relations Department learners in the University of Darussalam Gontor illustrated that there were numbers of low proficient learners with less vocabulary and poor grammar competence due to inappropriate teaching material or coursebook. The condition led to a barrier to listening skills. Suffering from inadequacy, learners often got lost when they were 
listening to the audio, and most of them had relied on guessing to answer the questions.

In the International Relations Department, IELTS has got an equal chance as well as other language skills. It is based on the 2015-set up a curriculum of the International Relations Department focusing on the mastery of listening, reading, writing, and speaking in the IELTS test to fulfill the requirements of graduate competence as stated in government regulation, number 19. All graduates are expected to master the language knowledge, language competence in order to communicate effectively and master in an instructional procedure so that learners can provide both input and linguistic in the process of teaching and learning.

As the research was carried out on the purpose of developing IELTS material for EFL learners' listening comprehension, it could be done through Research and Development (R\&D) design. R\&D produced and developed a user-need-product composed of teaching and media materials, behavior objectives, and also instructors (Brog and Gall, 1983). The research setting took the place of audio-visual supported language laboratory in the International Relations Department of the University of Darussalam Gontor. The subject of the research were three listening instructors of IELTS lecturers and the first semester learners of the International Relations Department encountering six meetings of IELTS listening practice tests.

The adapted model of developing listening materials needed surveying (based on Borg and Gall research and information), development of the materials (simplifying both second and third steps of Brog and Gall model), validation of expert and teacher (preliminary field testing), revision of main product (based on validation results of expert and teacher, try-out of the materials, revision, and the last is final product (Brog and Gall, 1983).

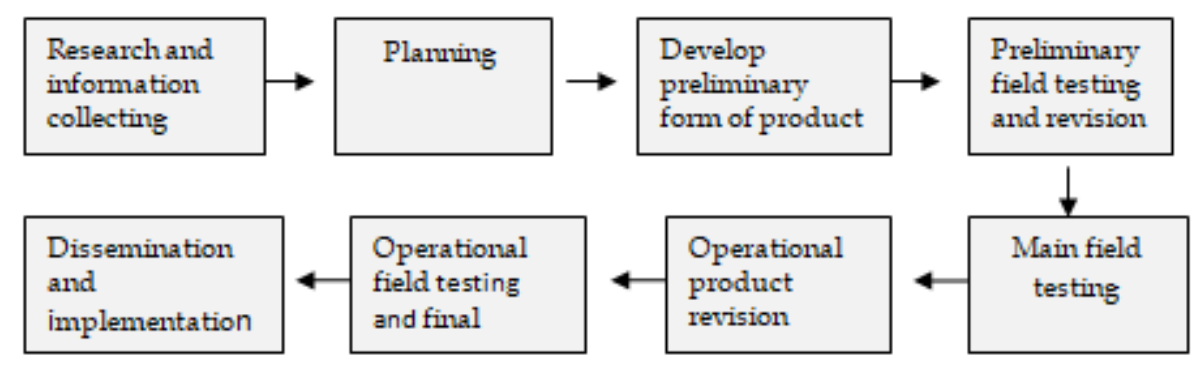

Figure 2.1. R\&D Cycle from Borg \& Gall

The phase in the study used situation and condition analysis of the teachinglearning process through instruments, which consisted of an interview guide, field note of observation, as well as a questionnaire sheet consisting of 8 questions. The questionnaire gathered information dealing with the background of the learners, their learning experience, and their listening opinion. An interview with the listening instructor was also conducted to follow up on the questionnaire sheet. The information related to listening materials' needs was derived through the instrument, which was strengthened by the field note of observation.

The second phase was the prototype development of listening materials. The instructor arranged the materials that included the topic, objectives, indicators, and primary and extension activity. The topics ware selected based on the IELTS syllabus. Similarly, the objectives and the indicator were constructed based on the IELTS 
syllabus. The main activities were held based on the suggestion of instructors; the extension activities, including the macro skill of listening, were referred to the listening characteristics.

The instructors were responsible for giving the suitability validation of the text length, the speed of delivery, and the distributed materials toward the IELTS syllabus. The text had to be delivered at average speed instead of slowed down. The text length depended on what the particular tasks implemented to the given text. Likewise, the suitability of the material toward the IELTS syllabus was relevant to the objectives, together with the coverage. The validation results were expressed in qualitative comments consisting of three ranges: poor, fair, right. The last phase was trying out on prototyped materials. It aimed at finding out the clarity of the recording, speed of delivered text, and the difficulty level of materials. The data gathered were beneficial to spot the hindrances while employing the materials.

\section{Findings}

\subsection{Expert Validation}

The experts were the material experts having the duty to provide an opinion, suggestion, or correction to improve the learning resources. The experts defined that generally, either the task or activities concerned about teaching EFL learners to listen to the IELTS listening test, including summary completion, form filling, filling the map and plan and multiple questions. These were appropriate for learners to manage time wisely and improve learners' scores.

From the experts' judgment, the result of the questionnaire represented that the expert answered 'yes' for the aspect of the course goal. It meant that most materials were suitable for IELTS Syllabus. Furthermore, the objective of each listening practice was clear, and it was relevant to the IELTS competence. For the grammatical aspect, the expert answered 'partly.' It meant that the presentation of grammar was excellent, yet there was a little bit to fix. The experts argued 'yes' for the vocabulary aspect. It meant that the selection of lexical resources was appropriate with the target.

In addition to the questionnaire answer, the first expert also provided some suggestions. The first expert revealed that it was good material; however, it still needed to be fixed, especially mechanics and grammatical errors. The second expert stated that the text in practice four, which was too long, should be shortened to make them concise. Likewise, the instruction of labeling map and plan should be readable, so the test takers could understand what they had to do with the test.

\subsection{Instructor's Validation}

Listening materials were made by involving five speakers to record listening practice 1 to 6 . The speakers come from lecturers for the International Relations Department. Likewise, the materials were also adjusted to the IELTS syllabus for listening ability. The listening instructors took into consideration that the material for the IELTS listening test had been already good as it produced acceptable sound quality and offered learners to learn activities such as answering questions, following a route on a map, filling the form, and so forth.

Concerning the language, the instructor considered three components, including the suitability of the language level with learners, communicable, and coherent ideas in each practice. For the suitability of language level, the instructors 
judged suitable for all practices, except fair for monologue part of listening practice test 1 section three and four. He said that the monologue part should be set in an everyday social context so that learners would comprehend the context easily. Pertinent to communicative materials, the instructors said suitable for all listening practice tests as the texts were clear and easy to understand for learners. They also followed English rhetoric. Dealing with the coherence, the instructors judged good for listening practice tests 1 to 6 as the material given in each practice had been coherent in conveying the ideas.

\subsection{Revision}

Based on the instructors and the expert's comments, suggestions, and judgments of the materials, some sentences, and tasks on expert's note needed to be revised. Following the developed materials, the length of the dialogue and the relationship of materials with the IELTS listening syllabus should be fixed. The monologue and the dialogue which were too long were revised to be brief. Similarly, the materials which did not deal with the IELTS Listening syllabus were revised. Furthermore, the situational backgrounds were optimized to make a clearer text

Relevant to the instructor' note, some grammatical problems and unclear texts were fixed, e.g. (1) "the exercise club run by Mark Peter" was revised into "the exercise club is run by Mark Peter"; (2) "we can consider buying anything since Bali is known for having some of the best shopping centers" was corrected into "we can consider buying anything since Bali is well known for having some of the best shopping centers."

There were some tasks to revise in such a way to let them clearers, e.g. (1) labeling map and plan question: the map should be created clearer; (2) plan materials should be rearranged in such a way, so it was readable; (3) giving an answer done as an example in labeling plan question before the test takers answer the test in practice listening test 2 section 1 .

\subsection{Data and Analysis of the Try-Out}

The instructors had been already used to conducting the IELTS class in the language laboratory. Thus, it did not need to train them on how to operate the equipment in the language laboratory. The instructors also got the materials prepared in the Schoology platform, instructors' guide, as well as learners' worksheets. They were obligated to read the instructors' guide before trying out the listening materials. The discussion about scheduling the try-out was held by either the instructors or the researcher. Considering the real plain time of materials recorded in IELST practice listening test, the schedules of try-out conducted in 6 days

\subsection{The First Try-Out}

The first try-out was carried out to observe whether the instructor's guide or the recording had been already practical and whether the delivered materials through Schoology were useful to test IELTS listening comprehension. The data which was derived from try-out were classified into field note of observation, instructors' opinion, and learners' opinion toward the materials.

\subsection{Data Obtained from the Observation}

The essential points showing the materials of IELTS practice listening tests were useful to teach as follows: (1) the instructors played the recording well; (2) IELTS 
listening class promoted learners' engagement through active learning; (3) learners had been brave enough to ask the instructor when they got difficult words; (4) learners learned practice listening test 2 section one enthusiastically as they were more challenging to answer filling form completion; (5) during teaching-learning process, the instructors applied practice listening test 1 composed of 4 sections, yet section 4 was not employed due to the limited time; (6) when the try-out was carried out, learners argued that they preferred to have listening class in language laboratory; $(7)$ using Schoology for IELTS listening class could potentially transform learning and improve learners' collaboration and engagement in listening class

\subsection{The Learners' Opinion on the Materials}

Learners were requested to answer the questionnaires about the material relevant to recording quality, attractiveness, and also delivery speed after each of the listening practices had been learned. Pertinent to the recording clarity, $50.86 \%$ of learners considered the materials were very good, 39.2\% of the learners argued that the materials were good, and $9.94 \%$ considered them fair. Dealing with the attractiveness, $25,49 \%$ of learners considered the materials were perfect, $58,7 \%$ of the learners defined that the materials were right, and 15,81\% argued that the materials were fair. Pertinent to the speed delivery, $28 \%$ of learners stated that the materials were excellent, 40,02\% considered them good, and 31,98\% considered them fair.

\subsection{The Result of the Learners' Tasks}

The learners' of listening practices 1 to 6 were gathered from trying out. Besides, the mastery of classroom learning had to be involved in consideration. Based on the data obtained from the instructors, in case $80 \%$ of the learners had already passed the minimum standard of band score (6.5), the listening materials were appropriate for EFL learners in the term of classroom learning material along with a level of difficulty. On the other hand, learners who had not passed 6.5 band score were obligated to join the remedial test.

Based on the result of learners' worksheet, it could be concluded that most of the IELTS listening practice tests had fulfilled the criteria of the proper materials for learners in the term of difficulty. There were only four topics, particularly in long monologue sections, and labeling maps and plans were still considered too hard for learners. Two topics were in practice listening to one, one topic is listening practice three, and the other was on listening practice test 6 . The mastery of classroom learning of listening practice one was $32 \%$, listening practice 2 was $41 \% \%$, and listening practice 3 was $46 \%$. Thus, the difficulty level of these three listening practice tests should be fixed.

\subsection{Instructors' Opinion}

Having tried out each of the listening practices, the instructors evaluated their product. They expressed their opinions into two aspects i.e. the effectiveness and the practicality of materials. The effectiveness as indicated by the materials usefulness for IELTS listening class and the practicality was characterized by the ease of preparing the IELTS practice listening test on Schoology and implementing it in the IELTS listening class.

The instructors argued that the recorded IELTS listening test 1 to 6 were easy to implement through Schoology-based e-learning. They said that Schoology could 
enhance learners' performance and also foster their engagement with their listening comprehension. On the other hand, they argued that the instructors' guides were able to direct them on how to build an effective teaching-learning process. Dealing with the effectiveness, the IELTS listening test could enhance learners' motivation to study English and optimize their listening band score.

\subsection{Revision}

The data derived from try-out considered that the material for IELTS listening practice tests did need to revise in the term of delivery speed, effectiveness, practicality, clarity of the recording, and attractiveness. In contrast, the term of difficulty level was remarkable to be improved as two topics in listening practice one, one topic of listening practice three, and one topic of listening practice test 6 was too tricky for EFL learners

Simplifying IELTS listening practice 1 to 6 was done to revise learners' task. For listening practice one, the revision was related to the monologue part in listening practice 1: sections 3 and 4 . The monologue was set in an everyday social context dealing with a school project; therefore, learners got a better understanding of the context. The revision in listening practice test three was done in section 2 . Section two was revised by providing an example answer. Looking at the example answer, learners knew the strategy to follow the direction of labeling map questions. Revision of IELTS listening practice six was done for section 3 for multiple-choice questions. In the section, learners should have to match one of the numbers of pictures with multiple choices. Section three was fixed by facilitating the specific picture referring to the proper answer, so learners can differentiate which one the correct answer was.

\subsection{The Second Try-Out}

Only section 3 and 4 in IELTS listening practice 1, section 2 of listening practice three, and section 3 of listening practice before were tried out. The try-out results defined that most of the learners had already passed the minimum standard of band score. It meant that they got successful in achieving learning mastery. For sections 1 and 2 of listening practice 1, all learners could catch up with the minimum standard of band score. Similarly, $87 \%$ of the learners were able to obtain a minimum lousy score. From listening practice six particularly in section 3, 85 of the learners achieved the minimum band score of IELTS listening. Thus, no revision was required.

\subsection{The Final Product}

Having been validated by the instructors and the experts, revised based on their recommendations, tried out, and also revised accordingly, the final product was presented as well. The product was prepared for the first semester of the International Relations Department. It was composed of 6 IELTS listening practices, and each practice includes four sections. The product provided recorded materials including the instructors' guide as well as IELTS listening worksheet uploaded in the learning management system namely Schoology. Each of the dialogue or monologue had been recorded two times. Hence, the delivered recordings were practical to listen to.

The product consists of a preface, list of content, map of the materials, 6 IELTS listening practices tests, the script and sample answer in each practice, and the Schoology platform. The material map facilitates a topic, time allotment, and the indicators of every IELTS listening practice test. The suggested listening activities had 
been developed in the following principle of listening comprehension. Those principles were (1) learners made listening to the primary channel for listening to the new material; (2) it would be better to have discussion calling up learners' background knowledge for activating level skill; (3) learners had to comprehend clearly about what they should expect to do before they got starting to listen to. Prepared with specification, the instructors' guide was able to facilitate them to handle the process of listening activity. They would not feel reluctant to teach IELTS listening practice as the preparation was correctly completed.

The difference between this listening product and the popular products issued by a reputable publisher is that this listening material is adjusted to learners' listening ability. This listening product is composed of 6 tests with the following explanation: IELTS practice listening test 1 and 2 are implemented for primary users; IELTS practice listening test 3 and 4 for independent users; and IELTS practice listening test 5 and 6 for proficient users. Thus, setting the difficulty level for questions in IELTS listening, learners can adjust test questions according to their abilities.

\section{Discussion}

The result of the needs survey had enlightened on demand to the listening materials availability which taught learners' listening comprehension. As advised by some researchers, the prototype of IELTS listening practice tests proper for level learners of IELTS test takers relied on this following discussion.

Based on the listening instructors' opinion, most of the learners this semester suffered from poor English proficiency specifically in major, although English had been learnt years before they decided to proceed to University. Learners' poor ability was reflected from lexical resources shortage, less of English encounter, lack of motivation to learn, and self-confidence appalling. Some instructor argued that less competitiveness in their class climate contributed to the condition

According to Kranshen's concept, the delivered material was supposed to be one level higher than the learners' knowledge (Krashen \& Tracy, 1983). Some factors were considered affecting the message understanding, including basic of speech, ungrammatical form, rate of delivered speech, pausing, errors of speech, the content of information, and linking words. The next consideration was the outline of learned materials should include a definition of every chapter, listening skill taxonomy, standard competence, the objective of learning, pre, while, and post-listening activities, listening comprehension, and listening practices. It was also supported by the transcript of IELTS listening practice tests, the answer key, the recorded materials as well as the Schoology platform to facilitate online test-based IELTS.

Accordingly, the instructors and learners recommended the number of the listening process. The instructors suggested the following activities, i.e., understanding numbers and alphabets, labeling map and plan, writing no more than three words to fill the completion of the sentence, and pronunciation practice. Meanwhile, learners proposed these activities including multiple-choice, short completion, filling the form, and pronunciation rehearsal.

Moreover, the instructors tend to prefer the recorded materials in a podcast file, and it was also uploaded in the Schoology platform in order to be accessible. With the existence of Schoology with its better features, learners were able to practice the IELTS listening test anytime and anywhere. The prototyped of the IELTS listening test 
provided six official meetings packed in 6 IELTS listening tests. Part of the materials had been adapted from current IELTS such as Basic Tactic for Listening (Richard, 2003), IELTS Preparation Class ( Lougheed, 2017), Top-Up Listening (Coone, et al., 2008), Prepare for IELTS: Academic Practice Test (Larbalestier, et al., 2016), and IELTS online websites like https://www.google.com, https://ieltsliz.com/, and https://www.youtube.com/user/IELTSOfficial

\section{Conclusion}

The final product of this research and development was recorded material of IELTS listening uploaded in the Schoology platform, practice, the instructors' guide together with learners' worksheet. The product is also composed of IELTS listening practice 1 to 6 for the first semester i.e. table/note/form/summary/flow-chart completion, map/diagram labeling/plan, matching, and multiple-choice questions, short-answer, and sentence completion. Secondly, referring to the finding of expert validation as well as the try-out, it can be summed up that the recorded material of IELTS listening was applicable for the learner in the term of level of difficulty, style of delivery, speed of delivery, and language content. The product can increasingly motivate learners to learn IELTS as those materials are relevant to learners' needs and based on the IELTS syllabus.

The suggestions are proposed, which might be considered for those who will carry out similar research together with the instructors who will apply the product. The presented suggestions are as follows: (1) other researchers may do further research to develop IELTS reading practice test, IELTS writing practice test, IELTS speaking practice test by exploring the same methodology; (2) the instructors are recommended to apply this product of this research as IELTS listening practice tests developed using Research and Development design; and (3) before employing the product, instructors are suggested to encourage their learners and to motivate them to be relaxed enjoying IELTS listening practice test; they will not be panic missing something in their listening practice.

\section{References}

Ahmadi, S. M. (2016). The Importance of Listening Comprehension in Language Learning. 7 International Journal of Research in English Education, 1(1), 7-10.

Atmoko. (2018). Designing Integrated English Materials Using Schoology to Boost Students' Engagement in SMPN 2 Klaten. Yogyakarta: Universitas Sanata Dharma.

Batova, N. (2013). Academic listening: is there a place for bottom-up processing International Journal of Education and Research, 1(4), 1-10.

Borg, W.R. \& Gall, M.D. Gall. (1983). Educational Research: An Introduction, Fifth Edition. New York: Longman.

Brown, H. D. (2001). Teaching by principles: An interactive approach to language pedagogy. New York: Addison Wesley Longman, Inc.

Celce, M. (2001). Teaching English as a Second or Foreign Language 3rd Edition. New York: Heinle and Heinle Thompson Learning, Inc.

Chalmers, J., \& Walkinshaw, I. (2012). Reading strategies in IELTS tests : Prevalence 
and impact on outcomes. 24 English Australia Journal, 30(1), 24-39.

Gilakjani, A. P., \& Ahmadi, M. R. (2011). A Study of Factors Affecting EFL Learners ' English Listening Comprehension and the Strategies for Improvement. Journal of Language Teaching and Research, 2(5), 977-988. https:// doi.org/10.4304/jltr.2.5.977-988

Hyland, K. (2003). Second language writing. Cambridge: Cambridge University Press

Krashen, S. \& Tracy, T. (1983). The natural approach: language acquisition in the classroom. Oxford: Pergamon Press.

Lougheed, L. (2010). Barron's IELTS: International English Language Testing System. Tangerang: Binarupa Aksara

Syafi'i \& Gestanti. (2017). Developing English Materials for EFL Learners at Islamic Junior High School. JEELS, 4(2), 199-220.

Syafi'i, M. L. (2016). Developing Listening Materials for the Tenth Graders. Journal of Education and Linguistics Studies, 3(1), 63-84.

Tabrizi, A. (2017). The Effect of IELTS Listening Strategy Use on the Reduction of IELTS Listening Test Anxiety and on IELTS Listening Performance. Theory and Practice in Language Studies, 7(11), 1025-1036.

https:// doi.org/http:/ / dx.doi.org/10.17507/tpls.0711.11

Tigowati1, Efendi, B. (2017). E-learning berbasis schoology dan edmodo : ditinjau dari motivasi dan hasil belajar siswa smk. Elinvo (Electronics, Informatics, and Vocational Education), 2(1).

Todd, V. \& Cameron, Penny. (2005). Prepare for IELTS: academic practice test. Sydney: Insearch and International Programs

Underwood, M. (1993b). Effective class management: A practical approach. London and New York: Longman.

Vilmane Liubiniene. (2019). Developing Listening Skills in CLIL Developing Listening Skills in CLIL Vilmante Liubinienè. Developing Listening Skills in CLIL, 3(1). https://doi.org/1648-2824

Yaniafari, R. (2014). Developing Multimedia-Based Listen Material for 1st Grade Students of SMK. The 3rd UAD TEFL International Conference 2014.

Yeldham, M. (2018). L2 Listening Instruction : More Bottom-up or More Top-down? The Journal of ASIA TEFL, 15(3). https:/ / doi.org/10.18823/asiatefl.2018.15.3.805

Zulyadaini. (2017). A Development of Students ' Worksheet Based on Contextual Teaching and Learning. IOSR Journal of Mathematics, 13(1), 30-38. https:/ / doi.org/10.9790/5728-1301033038. 